\title{
A note on the effect of Gliricidia sepium leaf meal on the growth performance and carcass characteristics of broiler chickens ${ }^{*}$
}

\author{
J.K. Kagya-Agyemang ${ }^{1}$, G. Takyi-Boampong, M. Adjei \\ and F.R. Karikari-Bonsu
}

\author{
Department of Animal Science, University of Education \\ Winneba, P. O. Box 40, Mampong-Ashanti, Ghana
}

(Received 19 September 2006; accepted 2 February 2007)

\begin{abstract}
A five-week feeding trial was conducted using $180 \mathrm{Cobb}$ commercial broiler chickens to study the inclusion of sun dried Gliricidia sepium leaf meal (GLM) in broiler diets. The 21-day-old chickens were randomly allocated to four dietary treatments. Fifty, 100 and $150 \mathrm{~g} \mathrm{~kg}^{-1}$ levels of GLM were included in a nutritionally balanced diet. The control diet did not contain GLM. Feed and water were supplied ad libitum. Feed intake, feed conversion efficiency and body weight gains were significantly $(\mathrm{P}<0.05)$ depressed by the addition of GLM to the diets. Dietary treatment had a significant impact on liver and gizzard weights. The abdominal fat content of carcass decreased progressively with increased levels of GLM. The carcass dressing percentage in the group fed diet with $15 \%$ GLM was lower $(\mathrm{P}<0.05)$ than in control group. No mortality was recorded throughout the study. As the level of dietary GLM increased, there was a corresponding increase in the intensity of yellow pigmentation of the skin, shanks, feet and beaks of birds. It seems that $50 \mathrm{~g} \mathrm{~kg}^{-1} \mathrm{GLM}$ can be included into diets of broiler chickens.
\end{abstract}

KEY WORDS: Gliricidia sepium, nutritive value, broilers, growth performance

\section{INTRODUCTION}

Gliricidia sepium (Jack) is a leguminous plant found in the tropics. In many tropical countries it is used as browse plant for ruminants, live fencing, shade for plantation crops (e.g., cocoa and coffee), green manure, support for yam vines

\footnotetext{
* The authors are grateful to the Department of Animal Science, University of Education, Winneba, Mampong Campus for funding the trial

${ }^{1}$ Corresponding author: e-mail: j.kagyaagyemang@abdn.ac.uk
} 
and demarcating boundaries. Despite the fact that gliricidia is used as a browse plant for livestock, little systematic study of its nutritive value has been carried out (Gohl, 1975; Chadhokar, 1982; Osei et al., 1990). Work done show that the leaves of gliricidia contain high levels of high quality protein (Senthoshanmuganathan and Durand, 1969; Osei et al., 1990; Odunsi et al., 2002) and of calcium, and adequate concentrations of other mineral elements (Chadhokar, 1982; Osei et al., 1990). These qualities make gliricidia very attractive as a potentially useful nonconventional feedstuff for poultry. Mishara et al. (1977) fed diets containing 50, 100 , and $150 \mathrm{~g} \mathrm{GLM} \mathrm{kg}^{1}$ to White Leghorn pullets for 14 weeks and reported that GLM up to $100 \mathrm{~g} \mathrm{~kg}^{-1}$ diet did not affect performance. However, when the birds were fed at $150 \mathrm{~g} \mathrm{~kg}^{-1}$ diet, the feed intake, growth rate and FCE were depressed. Similar observations were made by Ranaweera et al. (1981) in broiler chicken studies. In another study, Osei et al. (1990) made quite similar observations when they fed diets containing 25, 50 and $75 \mathrm{~g} \mathrm{GLM} \mathrm{kg}^{-1}$ to layers for 11 weeks and reported that feed consumption, hen-day egg production, FCE, and body weight

gains were significantly depressed by the addition of GLM to the layer diets. This study was therefore undertaken to investigate the effects of varying levels of GLM on the growth performance and carcass characteristics of commercial broilers.

\section{MATERIAL AND METHODS}

The gliricidia leaves used in the trial were harvested fresh from plants used for live fencing and hedges in Mampong town and around the University of Education, Winneba, Mampong campus, at between 8 and 11 weeks of re-growth. The leaves were mixed and sun-dried on a concrete drying surface for 4 days. The dried leaves were ground in a maize mill to produce gliricidia leaf meal (GLM). Representative samples were subjected to proximate analysis.

One hundred and eighty unsexed Cobb commercial broiler chickens aged 21 days were weighed and allocated in equal numbers to four experimental groups $\left(0,50,100\right.$ and $\left.150 \mathrm{~g} \mathrm{~kg}^{-1} \mathrm{GLM}\right)$ such that the group of birds were equalized for sex and weight. The trial was conducted according to the completely randomized scheme; each dietary treatment was replicated three times and each replicate had 15 birds. The experimental house was divided into 12 compartments using wire mesh as partitions. Each group of 15 birds were housed in a compartment measuring $3.4 \times 1.16 \times 2.20 \mathrm{~m}$. Feed and water were supplied ad libitum. The trial lasted 5 weeks.

The feed intake and liveweight gain were measured and feed conversion efficiency (FCE) calculated. On the final day of the trial, 4 broilers were selected randomly from each treatment replicate and slaughtered for carcass analysis. 
The analysis of variance was used in data analysis and significant differences among treatment means were estimated using Fisher's least significance difference test (Steel and Torrie, 1980).

Table 1. Composition of experimental diets, $\mathrm{g} \mathrm{kg}^{-1} \mathrm{DM}$

\begin{tabular}{lrrrr}
\hline \multirow{2}{*}{ Item } & \multicolumn{4}{c}{ Dietary treatments, $\mathrm{g} \mathrm{kg}^{-1}$ diet } \\
\cline { 2 - 5 } Ingredient & 0 & 50 & 100 & 150 \\
gliricidia leaf meal & 0 & 50 & 100 & 150 \\
maize meal & 590 & 590 & 560 & 540 \\
wheat bran & 120 & 100 & 100 & 100 \\
fish meal & 100 & 90 & 85 & 80 \\
soyabean meal & 90 & 80 & 75 & 60 \\
groundnut cake & 70 & 60 & 50 & 40 \\
oyster shell & 10 & 10 & 10 & 10 \\
dicalcium phosphate & 10 & 10 & 10 & 10 \\
vitamin-mineral premix & 5 & 5 & 5 & 5 \\
salt & 5 & 5 & 5 & 5 \\
& & & & \\
Calculated analysis & & & & \\
crude protein & 200.5 & 30.5 & 40.1 & 40.5 \\
crude fibre & 30.2 & 30.9 & 30.7 & 30.6 \\
ether extract & 31.0 & 11.9 & 11.6 & 11.5 \\
ME, MJ kg ${ }^{-1}$ & 12.3 & & & \\
\hline
\end{tabular}

\section{RESULTS AND DISCUSSION}

The composition of experimental diets are given in Table 1 .

The GLM contained, $\mathrm{g} \mathrm{kg}^{-1} \mathrm{DM}$ : crude protein, 18.2; crude fibre, 12.9; ash, 18.2; ether extract, 2.7; N-free extractives, 48.0, and dry matter, 92.8. These data are comparable with those reported by Osei et al. (1990) and Odunsi et al. (2002) except that the ash and crude protein contents were quite lower. The slight differences in nutrient status of GLM might be partly due to differences in plant maturity, site, climate and genotype.

The effects of GLM on broiler performance are summarized in Table 2. Feed intake, body weight gain and FCE significantly $(\mathrm{P}<0.05)$ decreased as the level of GLM increased. A major factor affecting feed intake in poultry is the dietary energy content (Osei et al., 1990) because birds eat to satisfy their energy requirements. In this trial however, it appears that the reduced feed intake and FCE were due to the increasing fibre content of the diets incorporating GLM (Osei et 
Table 2. Effect of Gliricidia sepium leaf meal on the performance of broiler chickens (21-56 d of age)

\begin{tabular}{lccccc}
\hline \multirow{2}{*}{ Parameter } & \multicolumn{5}{c}{ Dietary treatments, g GLM kg-1 diet } \\
\cline { 2 - 6 } & 0 & 50 & 100 & 150 & SEM \\
\hline Initial body weight, kg & 049 & 0.49 & 0.49 & 0.49 & - \\
Final body weight, kg & $2.59^{\mathrm{a}}$ & $2.31^{\mathrm{b}}$ & $1.88^{\mathrm{c}}$ & $1.61^{\mathrm{d}}$ & 0.07 \\
Body weight gain, kg & $2.10^{\mathrm{a}}$ & $1.82^{\mathrm{b}}$ & $1.39^{\mathrm{c}}$ & $1.12^{\mathrm{d}}$ & 0.08 \\
Feed intake, kg & $4.43^{\mathrm{a}}$ & $4.40^{\mathrm{b}}$ & $4.25^{\mathrm{c}}$ & $3.81^{\mathrm{d}}$ & 10.19 \\
FCE, kg feed/kg BWG & $2.11^{\mathrm{a}}$ & $2.42^{\mathrm{b}}$ & $3.06^{\mathrm{c}}$ & $3.41^{\mathrm{d}}$ & 0.07 \\
Dressing percentage & $82.6^{\mathrm{a}}$ & $79.3^{\mathrm{ab}}$ & $77.6^{\mathrm{ab}}$ & $76.5^{\mathrm{b}}$ & 9.6 \\
Abdominal fat, \% LBW & $2.40^{\mathrm{a}}$ & $2.27^{\mathrm{a}}$ & $1.77^{\mathrm{b}}$ & $1.70^{\mathrm{b}}$ & 0.06 \\
Liver weight, \% LBW & $2.17^{\mathrm{a}}$ & $2.41^{\mathrm{b}}$ & $2.97^{\mathrm{c}}$ & $3.47^{\mathrm{d}}$ & 0.19 \\
Gizzard weight, \% LBW & $1.61^{\mathrm{a}}$ & $1.78^{\mathrm{a}}$ & $2.22^{\mathrm{b}}$ & $2.62^{\mathrm{c}}$ & 0.18 \\
\hline
\end{tabular}

a,b,c,d different at $\mathrm{P}<0.05$

al., 1990) or it may also be due to other anti-nutritional factors present in GLM (Ranaweera et al., 1981). These compounds include tannins, alkaloids and nitrates (Osei et al., 1990) that can reduce palatability of diets with GLM.

There was significant $(\mathrm{P}<0.05)$ dietary treatment effect on the mean gizzard and liver weights when expressed as percentage of live body weight of broilers in each group. There was a corresponding increase in the gizzard and liver weights of broilers fed diets with GLM. The increase in weight of these organs is probably in response to the effects of the toxic/anti-nutritional factors in the diets incorporating GLM. Again, the increase in weight of the liver probably serves to process the feed to aid absorption of nutrients from the gut.

There were no deaths or health related problems recorded during the study. This observation is in line with the report made by Ranaweera et al. (1981) that GLM up to $100 \mathrm{~g} \mathrm{~kg}^{-1}$ had no influence on the survival of broilers when it replaced coconut meal in broiler diets.

The intensity of yellow pigmentation of the shanks and feet, beaks and skins of broilers increased with increased levels of GLM in the diets from almost white in the control group to very deep yellow in treatment with $150 \mathrm{~g} \mathrm{~kg}^{-1} \mathrm{GLM}$.

There was a significant dietary treatment effect when abdominal fat was expressed as percentage of the live body weight of broilers in each group. The abdominal fat content of the control birds was significantly $(\mathrm{P}<0.05)$ higher than that of birds in treatments three and four. As a result, treatments three (100 $\left.\mathrm{g} \mathrm{kg}^{-1} \mathrm{GLM}\right)$ and four (150 $\left.\mathrm{g} \mathrm{kg}^{-1} \mathrm{GLM}\right)$ had the best carcass quality in comparison with the control birds and those in treatment two $\left(50 \mathrm{~g} \mathrm{~kg}^{-1} \mathrm{GLM}\right)$ showing the poorest carcass quality.

The carcass dressing percentage of the control birds was comparable with that fed with GLM. However, it was significantly $(\mathrm{P}<0.05)$ lower than that of birds fed diet with $15 \%$ GLM. 
The results of this study suggest that sun-dried Gliricidia sepium leaves may be incorporated into broiler diets up to $5 \%$.

\section{ACKNOWLEDGEMENTS}

We are grateful to Professor S.A. Osei, Professor P.K. Kwakye and an anonymous animal science lecturer for useful discussions and helpful and constructive comments on the earlier version of the manuscript.

\section{REFERENCES}

Chadhokar P.A., 1982. Gliricidia maculate. A promising legume plant. World Anim. Rev. 44, 3643

Gohl B.I., 1975. Tropical feeds: feed information summaries and nutritive values. FAO. Animal Production and Health Series. No. 12 FAO, Rome, pp. 165

Mishara M., Singh I., Sahoo G., 1977. Effect of feeding Gliricidia maculate leaf meal on the performance of White Leghorn chicks. Indian J. Poultry Sci. 12, 17-21

Odunsi A.A., Ogunleke M.O., Alagbe O.S., Ajani T.O., 2002. Effect of feeding gliricidia leaf meal on the performance and egg quality of layers. Int. J. Poultry Sci. 1, 26-28

Osei S.A., Opoku R.S., Atuahene C.C., 1990. Gliricidia leaf meal as an ingredient in layer diets. Anim. Feed Sci. Tech. 29, 303-308

Ranaweera K.N.P., Siriwardene J.A. de S., Manamperi H.B., 1981. The feeding value of gliricidia leaf meal for broiler chickens. Ceylon Vet. J. 29, 4-6

Senthoshanmuganathan S., Durand S., 1969. Isolation and composition of proteins from leaves of plants grown in Ceylon. J. Sci. Food Agr. 20, 603-608

Steel R.G.D., Torrie J.H., 1980. Principles and Procedures of Statistics: a Biometrical Approach. $2^{\text {nd }}$ Edition. McGraw Hill, New York 